POLITYKA ENERGETYCZNA - ENERGY POLICY JOURNAL

$2021 \downarrow$ Volume $24 \uparrow$ Issue $1 \uparrow 133-152$

DOI: $10.33223 / \mathrm{epj} / 131829$

Natalia Pryshliak ${ }^{1}$, Dina ToKarchuK ${ }^{2}$, Hanna ShevchuK $^{3}$

\title{
The socio-economic and environmental importance of developing biofuels: the Ukrainian case on the international arena
}

ABSTRACT: The beginning of the XXI century was marked by a transitional period in the formation of the world energy system. The issue of energy saving is characterized by significant diversity and is a necessary strategic direction for the efficient use of production capacity with optimal energy costs. Intensive economic development and the use of non-renewable natural resources are currently of concern due to the danger of disturbing the ecological balance in the environment due to the burning of huge amounts of fossil fuels and emissions of various harmful substances. Biofuel production is becoming an alternative to traditional energy and can be a guarantee of solving problems of energy efficient and environmentally friendly development of rural areas. This work is a continuation of research work on the efficiency of biofuels production from energy crops and waste. The aim of the research is to assess the importance of biofuels production from the energy, economic and social aspects for sustainable development of rural areas of the world and Ukraine in

$\triangle$ Corresponding Author: Natalia Pryshliak; e-mail: natalka.vinn@gmail.com

1 Management and Law, Vinnytsia National Agrarian University, Ukraine; ORCID iD: 0000-0002-0544-1441; e-mail: natalka.vinn@gmail.com

${ }^{2}$ Management and Law, Vinnytsia National Agrarian University, Ukraine; ORCID iD: 0000-0001-6341-4452; e-mail: tokarchyk_dina@ukr.net

3 Management and Law, Vinnytsia National Agrarian University, Ukraine; ORCID iD: 0000-0001-6094-0414; e-mail: shevchukhv@gmail.com

2021. The Author(s). This is an open-access article distributed under the terms of the Creative Commons Attribution-ShareAlike International License (CC BY-SA 4.0, http://creativecommons.org/licenses/by-sa/4.0/), which permits use, distribution, and reproduction in any medium, provided that the Article is properly cited. 
particular. The conducted SWOT-analysis made it possible to determine the strategic directions of world biofuels production development. The results showed that biofuels production has a significant potential to decarbonize the economy, reduce reliance on crude oil, improve the environment by reducing emissions, create new "green" jobs in rural areas. The combination of social, economic and energy benefits will have a synergistic effect.

KEYWORDs: energy efficiency, ecology, biofuels, rural development, social effect

\section{Introduction}

The beginning of the $21^{\text {st }}$ century was marked by a transitional period in the formation of the world energy system. Currently, the topical problems of the economy are the growth of current production costs and specific investment in the energy sector, the formation of a favorable economic climate for the further development of the fuel and energy complex, the development by the world community of advanced regulation methods and the coordinated global energy development strategies. At the same time, improving the standard of living of the population and its socio-economic condition will largely depend on the rational use of energy carriers and natural resource potential, which at the present stage of management is becoming especially relevant.

The socio-economic need to provide most countries with their own energy sources raises the problem of finding alternative fuels. At the same time, the environmental damage from emissions from cars running on petrol and diesel is becoming more and more noticeable.

Regarding the substantiation of the economic and social necessity of the formation and development of the biofuels market, several factors should be taken into account, starting from energy security considerations, the diversification of national production, support of innovations and ending with economic and social efficiency of biofuels market development based on high motivation, social shift in rural employment growth and environmental security through renewable energy sources.

\section{Literature review}

Fuel energy use worldwide continues to grow. According to the International Energy Agency global energy demand increased by $0.9 \%$ in 2019 , i.e. 120 million tons of oil equivalent, $40 \%$ the rate of growth observed in 2018. Slower economic growth and weather conditions explain most of the slowdown (IEA 2019). According to Guo, 2020 bioenergy has been ranking number one 
among all forms of renewable energy consumed by human beings. Over the past two decades, tremendous investments have been made in biofuel development and production.

Msangi et al. 2006, note that bioenergy has drawn attention as a sustainable energy source that may help cope with rising energy prices, but may also provide income to poor farmers and rural communities around the globe.

Ramos et al. 2016, investigate benefits and perspectives on the use of biofuels given an accent to the fact that the value of biofuels goes beyond their use as transportation fuels, and attention should be given to the economic and environmental benefits of the co-products of biofuels.

Berezyuk et al. 2019, discuss the resource potential of the use of waste as a component of the environmental and energy security of the state, proving that biofuels production from waste is of great importance.

Oh et al. 2018 emphasize that biofuels are regarded as one of the most viable options for the reduction of $\mathrm{CO}_{2}$ emissions in the transport sector.

Winchester and Reilly 2015, investigated feasibility, costs, and environmental implications of large-scale bioenergy by developing a detailed representation of bioenergy in a global economy-wide model. They developed a scenario with a global carbon dioxide price, applied to all anthropogenic emissions except those from land use change.

The importance of biofuels development for Ukraine was studied by (Kaletnik 2019; Geletukha et al. 2020; Zulauf et al. 2018) and others.

In previous studies by the authors (Pryshliak et al. 2020), a survey of heads of agricultural enterprises of various organizational and legal forms in different regions of Ukraine was carried out to determine the potential for biofuel production. The results of the study showed that the main focus is on the prospects for the production of biofuels from waste (biogas, solid biofuels). The greatest potential for biofuel production in Ukraine is in the central and southern regions, where the crop production industry (a source of feedstock for the production of bioethanol, biodiesel, solid biofuel) and the livestock industry (production of raw materials for the production of biogas) are developed. Most heads of agricultural enterprises indicated an interest in developing biofuel production, however, in case of the availability of state support.

Biofuels production, especially the first generation, is still controversial. The issue of socio-economic and ecological significance of the development of biofuels in the world and Ukrainian dimension needs a comprehensive analysis and generalization.

The research was conducted in order to evaluate the socio-economic and environmental benefits of biofuel production in Ukraine. 


\section{Materials and Methods}

The sources of the data used in this analysis are regulatory documents, statistical and analytical data of international governmental institutions, organizations, associations. Data analysis was conducted using descriptive statistics and graphic methods. Strengths, weaknesses, opportunities and threats of biofuels production are identified using the SWOT analysis.

\section{Results and discussion}

\subsection{World Perspective}

Oil occupies the largest share in the structure of total primary energy consumption $(31.5 \%$ in 2018), and is also the main raw material for the production of transport fuels in the world (IEA 2019). Oil is a fossil energy source, so its reserves are exhaustible and non-renewable. Leading scientists, world organizations and oil companies engaged in the study of oil reserves, predict various data on the possible timing of its depletion.

According to OPEC (The Organization of the Petroleum Exporting Countries), world proven crude oil reserves stood at 1,551 billion barrels at the end of 2019, increasing by 3.6 percent from the level of 1,497 billion barrels recorded at the end of 2018 (OPEC).

Currently, there are both optimistic and pessimistic forecasts about the possible timing of oil depletion. Thus, pessimists are of the opinion that the depletion of oil will occur in 20-25 years, while optimists predict that this will happen no earlier than 50-70 years. Pessimistic predictions about the complete depletion of oil reserves and, as a consequence, the global crisis may not come true if decisive measures are taken to limit its consumption (Kaletnik 2018).

Oil deposits are not available in all countries. They are mainly located in regions that are poor in fertile land and with a predominantly hot climate. According to OPEC Annual Statistical Bulletin, in 2019, the top three crude oil producing countries were the United States (12.23 million barrels/day), Russia (10.63 million barrels/day) and Saudi Arabia (9.81 million barrels/day). With an average of 99.67 million barrels/day in 2019, world oil demand grew by 0.9 percent. Accordingly, the volume of oil consumption in the world is constantly growing (Fig. 1).

Factors contributing to the growth of consumption of fuel and energy resources include: the development of scientific and technological progress; population growth; increase in the number of vehicles and transportation distances; improving the quality of life, accompanied by an increase in energy consumption (heating, lighting, use of various appliances), increasing the number of 


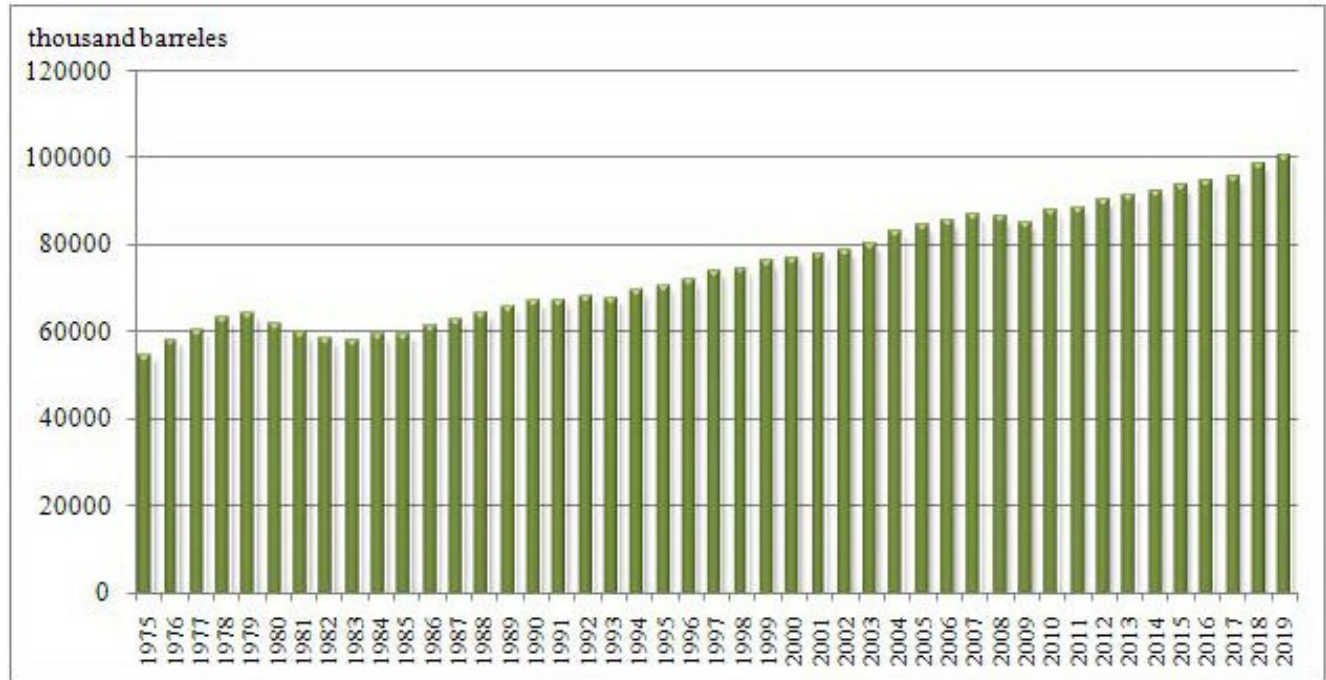

Fig. 1. World oil consumption [thousand bar/day]

Source: composed according to the data from (IEA 2019)

Rys. 1. Światowe zużycie ropy [tysiąc baryłek/dzień]

means of production, etc. Thus, according to the Organization for Economic Co-operation and Development (OECD), over the past 10 years, the world's population has increased by $13 \%$, the number of cars - by $50 \%$, and transport distances have increased by $65 \%$.

Along with the growth of oil consumption, its price also increases (Fig. 2). In 2008, 2014 and 2018, there was a sharp drop in oil prices on the world market. In 2008, this was due to the global economic crisis, which halted economic development in many countries. After almost five years of stability, oil prices have fallen by more than $40 \%$ since June 2014 , and began to decline particularly sharply after the OPEC ministerial meeting held in Vienna on November 27, 2014. The representatives of the largest oil producers countries failed to agree on a reduction in oil production and decided to keep its production at the same level. Representatives of the Organization of the Petroleum Exporting Countries (OPEC), trying to influence the world price of oil, began to reduce its production in September 2016. In mid-2019, the world oil market showed slow growth due to a number of external factors. However, even then it was clear that the underutilization of production capacity and falling global demand would not allow it to develop steadily.

One of the acute problems of the Earth is the increase in the concentration of carbon dioxide and global warming due to the growth of production and the processing of carbohydrates of technological progress. Over the past century, annual oil production has increased 20 times, the entire world is in the expected planetary energy crisis. At such a rate of carbohydrate consumption, according to expert estimates of international experts (Kaletnik 2019; Lindsey 2020), almost all fossil fuel reserves may be depleted over the next 40 years. 


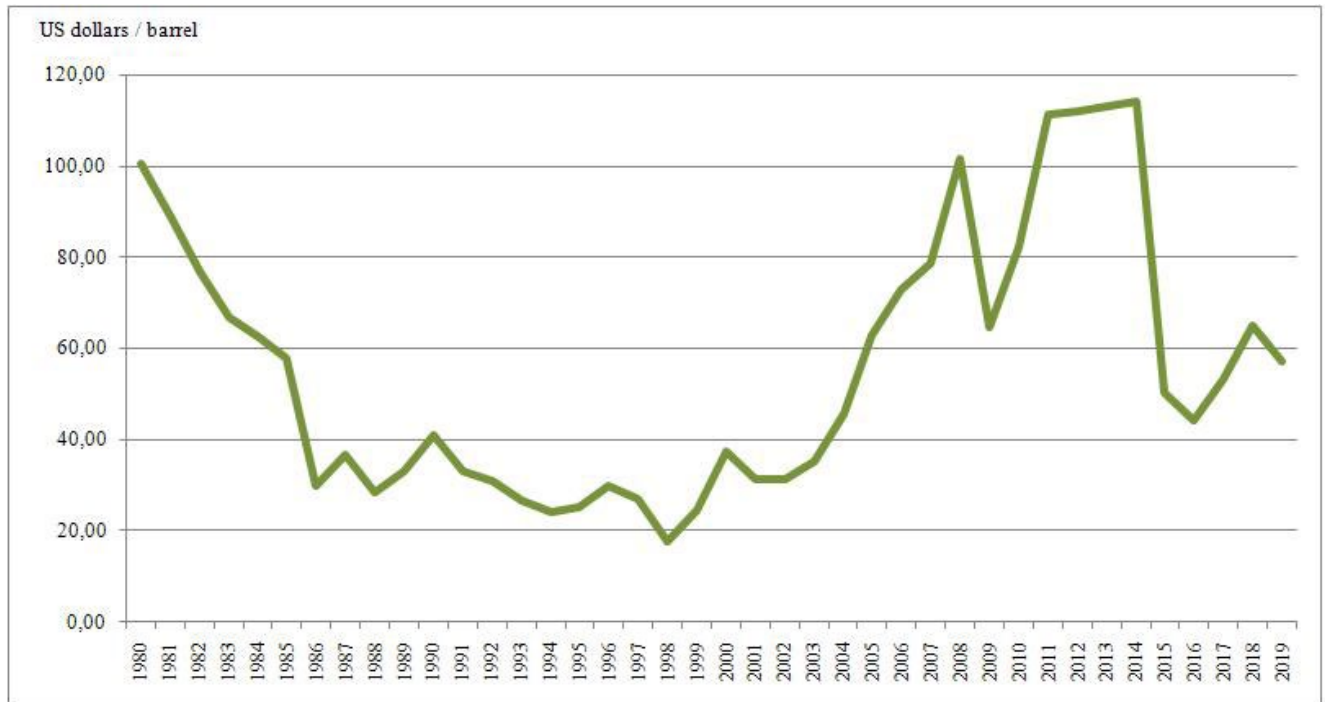

Fig. 2. Oil prices [US dollars/barrel], Brent oil

Source: composed according to the data from (IEA 2019)

Rys. 2. Ceny ropy [USD/baryłkę], ropa Brent

Climate change, acid rain, radioactive waste, oil spills, transport emissions threaten our health, the economy, and the environment. All this is a consequence of the inefficient use of energy resources and the environment by each of us and humanity as a whole. Global processes taking place in the modern world force us to comprehend and evaluate many phenomena of a socio-economic and, especially, environmental nature; to link them into a continuous stream of change and transformation; to look for new mechanisms of state management of these processes adequate to the requirements of time; to look for new alternative energy sources. The main principles of reducing anthropogenic emissions and increasing the sequestration of greenhouse gases are shown in Figure 3.

It is becoming increasingly clear that we need to limit the use of fossil fuels to a level at which the world's natural environment can cope with emissions. The main attention in the future should be paid not to the volume of stocks of all fuels, but to the amount that can be used without serious damage to the ecosystems on which our well-being depends.

Scientists (Lindsey 2020; Berezyuk 2019) estimate that only a quarter of the fossil fuel currently used and considered economically viable can be used in the 21 st century to limit climate change to a safe level where it is possible to avoid danger to the existence of ecosystems.

Therefore the main focus in the near future should not be on increasing the volume of fossil fuel extraction, but on determining its quantity, which can be used without the serious disturbances of ecosystems. The well-being of the world's population depends on this.

The use of biofuels provides the carbon dioxide cycle in nature, reduces the anthropogenic load on the environment by the processing of renewable agricultural feedstock. 
Basic principles of reducing anthropogenic emissions and increasing the sequestration of greenhouse gases

- minimization of adverse social, environmental and economic consequence of anthropogenic gas emissions;

- scientyfic validity, consistency and competence of the approach to reducing anthropogenic emissions and increasing seqestration of greenhouse gases;

- creation of stimulating conditions for business activities in the field of implementation of environmentally efficient technologies and echievements aimed at reducing anthropogenic emissions and increasing the sequestration of greenhouse;

- ensuring state regulation of economic entities in terms of reducing anthropogenic emissions and increasing the sequestration of greenhouse gases;

- formation and implementation of state policy and measures in accordance with the national condotions, set out in Article 2 of the Kyoto Protocol;

- regulation of greenhouse gas emissions taking into account economic feasibility, level of technological processes, technical condition of equipment and facilities in combination with market mechanisms of reduction of greenhouse gas emissions and increase of their sequestration, aimed at economic growth and stimulation of new technologies and innovations

- ensuring the economic attractiveness of investments aimed at improving environmental efficiency and reducing greenhouse gas emissions;

- use of market relations and competition as one of the main tools to promote environmental efficiency;

- stimulating the development of the energy complex on the basis of bioenergy, transport, utilities, resource-saving production, housing and related services, improving the environmental situation in Ukraine and improving the quality of life.

Fig. 3. Basic principles of reducing anthropogenic emissions and increasing the absorption of greenhouse gases Source: own study based on (Zulauf et al. 2018; Kaletnik et al. 2019)

Rys. 3. Podstawowe zasady ograniczania emisji antropogenicznych i zwiększania absorpcji gazów cieplarnianych

Depending on the type of raw material used for the production of biofuels, the following types are available:

$\downarrow 1 \mathrm{G}\left(1^{\text {st }}\right.$ generation biofuels $)$ - are obtained using traditional technologies from vegetable and animal fats, as well as starch and sugar. Basically, the sources of feedstock belong to the food 
group, which causes some criticism, since the production of biofuels reduces the amount of food and causes an increase in their cost. Another drawback is that this type of biofuel is quite expensive; its production requires additional support (subsidies) from the state;

$\checkmark 2 \mathrm{G}$ ( $2^{\text {nd }}$ generation biofuels $)$ - are obtained using biomass for production, consisting of non-food or residual parts of plants: husks, leaves, stems, as well as wood chips, pulp of vegetables and fruits, remains after squeezing the juice, etc. Modern technologies make it possible to obtain useful raw materials from fibrous or woody biomass, that contain lignin or sugar, from which biofuel is subsequently obtained;

\ $3 \mathrm{G}$ ( $3^{\text {rd }}$ generation biofuels) - is a promising technology that makes it possible to obtain inexpensive biofuels as a result of processing algae. Algae is a highly productive and at the same time inexpensive feedstock. One hectare of algae can produce 30 times more energy than a hectare of soybeans. A problematic issue is the allotment of areas where algae will be grown on an industrial scale.

Many countries around the world understand the benefits of biofuel production and are developing the bioenergy industry. In 2019, global biofuel production levels reached 1,841 thousand barrels of oil equivalent per day, in stark comparison to the 187 thousand barrels of oil equivalent per day that was produced in 2001 (Fig. 4). Growth has largely been driven by policies that encourage the use and production of biofuels due to the perception that it could provide energy security and reduce greenhouse gas emissions in relevant sectors (Tiseo 2020).

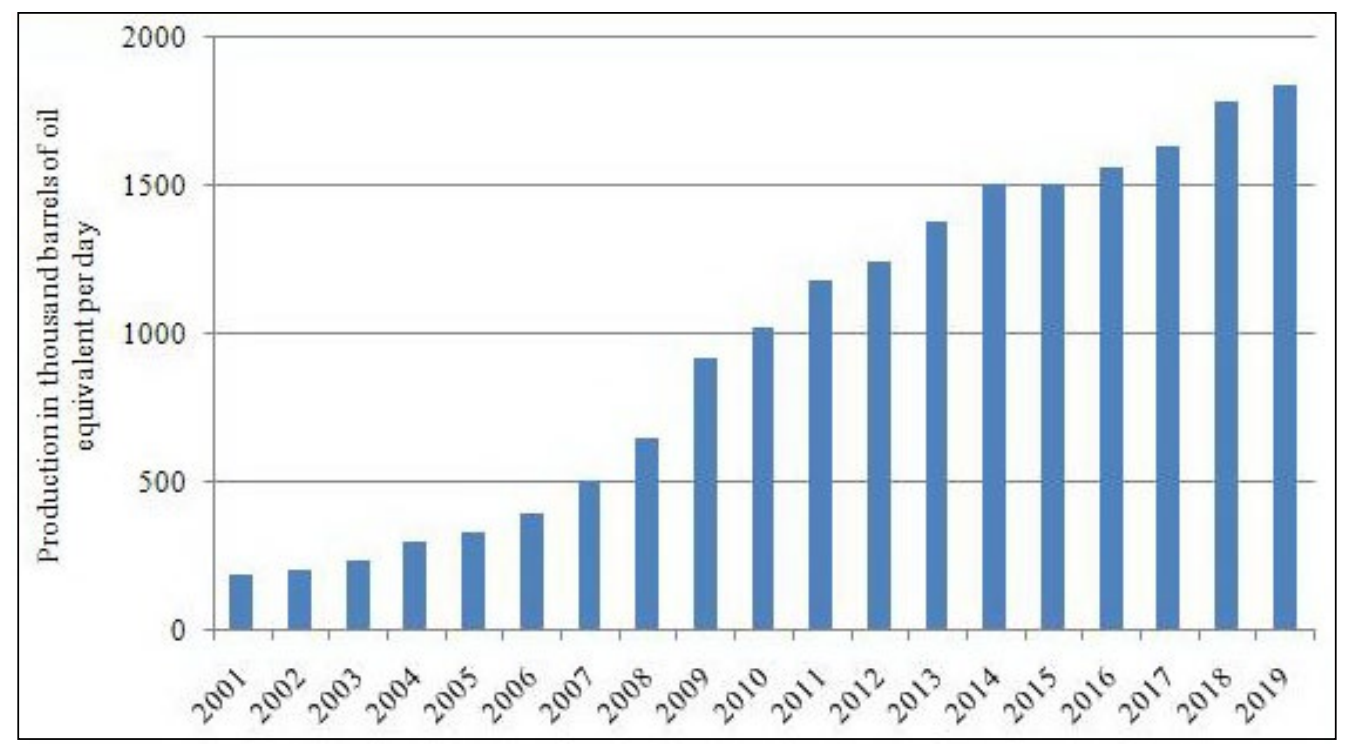

Fig. 4. Global biofuel production from 2000 to 2019 (in thousand barrels of oil equivalent per day); includes biogasoline (such as ethanol) and biodiesel. Volumes have been adjusted for energy content (Tiseo 2020)

Rys. 4. Globalna produkcja biopaliw w latach 2000-2019 (w tysiącach baryłek ekwiwalentu ropy naftowej dziennie); obejmuje biopaliwa (np. Etanol) i biodiesel. Wolumeny zostały dostosowane do zawartości energii 
Using the preceding discussion as a background, the main factors that will impact development of world biofuels production are identified using a SWOT analysis (Fig. 5). SWOT-is a strategic planning tool used to evaluate Strengths (S), Weaknesses (W), Opportunities (O), and Threats $(\mathrm{T})$ of a business venture. Factors internal to the venture are usually classified as strengths or weaknesses; factors external to the venture are usually classified as opportunities or threats.

\begin{tabular}{|c|c|c|}
\hline \multirow[b]{2}{*}{$\begin{array}{l}\text { 至 } \\
\text { Z } \\
\text { 至 } \\
\text { Z }\end{array}$} & STRENGTHS & WEAKNESSES \\
\hline & $\begin{array}{l}\text { 1. Possibility to reduce global atmospheric carbon } \\
\text { dioxide in order to prevent greenhouse effect (global } \\
\text { atmospheric carbon dioxide was } 409.8 \pm 0.1 \mathrm{ppm} \text { in } \\
\text { 2019, a new record high) (Lindsey } 2020 \text { ); } \\
\text { 2. Use waste as a raw material for biofuels solving } \\
\text { ecological problems (Berezyuk et al. 2019; Pryshliak } \\
\text { and Tokarchuk 2020); } \\
\text { 3. Biofuels are a renewable energy source (Tokarchuk } \\
\text { 2019); } \\
\text { 4. Can be produced locally (Kaletnik 2019). }\end{array}$ & $\begin{array}{l}\text { 1. Ignorance - users prefer traditional types of } \\
\text { energy (coal, natural gas, firewood) } \\
\text { (Pryshliak 2019); } \\
\text { 2. Need highly qualified workers (Oh et al. 2018); } \\
\text { 3. Lack of biomass supply logistics and biofuel } \\
\text { infrastructure (Uslu et al. 2018); } \\
\text { 4. The high costs of conversion technologies } \\
\text { (Winchester and Reilly 2015). }\end{array}$ \\
\hline \multirow[b]{2}{*}{ 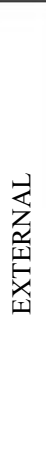 } & OPPORTUNITIES & THREATS \\
\hline & $\begin{array}{l}\text { 1. Reduce reliance on crude oil (Ramos et al. 2016); } \\
\text { 2. Possibility to create new "green" jobs and develop } \\
\text { rural areas (Fig. 7); } \\
\text { 3. Increase in consumption of energy resources that } \\
\text { will guarantee demand for biofuels (Fig. 1); } \\
\text { 4. The global development and consumption of } \\
\text { bioenergy and biofuels are steadily advancing } \\
\text { (Guo 2020); } \\
\text { 5. Might be the key to meet demands of energy being } \\
\text { eco-friendly and cost-effective (Voloshin et al. 2019); } \\
\text { 6. Forming energy independence from energy-importing } \\
\text { countries (Kovalko 2009). }\end{array}$ & $\begin{array}{l}\text { 1. Increasing demand for the manufacture of } \\
\text { biofuels will put a huge burden on agriculture } \\
\text { and food prices (Datta et al. 2019). } \\
\text { 2. Loss of habitat for various species of plants and } \\
\text { animals because more land would be require to be } \\
\text { cultivated for biofuel production (Shah 2012); } \\
\text { 3. Lack of assurance on socially responsible } \\
\text { practice in advanced biofuels supply chain (social) } \\
\text { (IRENA 2016); } \\
\text { 4. Uncertainties relating to goverment policies } \\
\text { (IRENA 2019). }\end{array}$ \\
\hline
\end{tabular}

Fig. 5. SWOT-analysis of biofuels production

Source: own study

Rys. 5. Analiza SWOT produkcji biopaliw

The results of the SWOT analysis allowed the following strategic guidelines for the development of biofuels production in the world to be determined:

$\checkmark$ decarbonization of the economy, including due to the development of bioenergy;

$\checkmark$ advanced training of workers and the use of advanced technologies for the production of biofuels on an industrial scale;

$\downarrow$ focus on the production of second and third generation of biofuels to avoid fuel versus food issues;

$\downarrow$ increasing the role of state incentives for the production and use of biofuels;

$\checkmark$ intensification of biofuel production in energy-deficient countries. 


\subsection{Ukrainian Case}

Ukraine is an energy-deficient country. According to the State Statistics Service of Ukraine, in 2017 Ukraine provided itself with its own energy resources by only $65.7 \%$. The annual use of oil products in Ukraine is about 15 million tons per year, of which 5 million tons of gasoline, 6 million tons of diesel fuel and 4 million tons of fuel oil. At present, crude oil production in Ukraine satisfies the needs of the national economy by only $6-10 \%$. The deficit of crude oil reserves and light oil products is covered by imports from Kazakhstan, Kyrgyzstan, Turkmenistan, Belarus and partially from the Baltic countries (Latvia, Lithuania and Estonia).

The previous dynamics of the increase in the cost of gasoline and diesel fuel is quite rapid, so in Ukraine it is advisable to take care of ensuring energy security.

To increase and strengthen the energy security of the state, the agriculture of Ukraine should not only be an energy consumer, but also an energy producer. According to technological standards, about 1.4 million tons of diesel fuel and 0.35 million tons of gasoline are needed annually for agricultural work (State Statistics Committee of Ukraine 2020). The production of this amount of fuel requires about 3.7 million tons of oil, which is mainly imported. In this regard, the constant growth of its value leads to an increase in the cost of oil products, and, consequently, agricultural products. So from 2000 to 2018, the costs of agricultural enterprises for the purchase of fuel increased 16 times.

The growth in the production and consumption of oil and its derivatives causes many negative effects, in particular, the formation of acid rain, climate change, the growth of emissions of harmful gases into the atmosphere, fires and accidents during the production and transportation of oil. These effects have a negative impact on human health, economic and environmental.

Scientists point out that Ukraine, like many other countries, will suffer from climate change. Our state is threatened by abnormal temperature conditions, the transformation of the steppes of the southern region into deserts, the flooding of the coastal regions of the Black and Azov Seas, and an acute shortage of drinking water in the southern and eastern regions. All this threatens the country's economic development in the next decades. It is the economic, environmental and social consequences that are forcing governments to implement new environmental policies, including policies to reduce greenhouse gas emissions.

In terms of greenhouse gas emissions, Ukraine is one of the twenty largest pollutants on the planet (State Statistics Committee of Ukraine 2020), but little attention is paid to solving this problem.

The main obligation of Ukraine under the UN Framework Convention, the Kyoto Protocol and the Paris Agreement is the implementation of a policy to reduce gas emissions by all sectors of the economy and the formation of relevant legislation. This work involves reviewing the existing strategies for the development of the energy, transport, industry, agriculture and housing and communal sectors in Ukraine, so that further economic development is accompanied by a decrease in the negative impact on the climate. 
The factors that determine the need for the production and consumption of biofuels in Ukraine are the exhaustion of fossil fuels, dependence on imports of fuel and energy resources, the constant growth of their cost, and the deterioration of the environmental situation. At the same time, the presence of natural resource potential makes it possible to grow a wide range of crops that can become raw materials for biofuel production. However, there is now a high rate of agricultural exports, which is unacceptable given the low employment rate in rural areas (Fig. 6) The total population in Ukraine is 42.1 million permanent residents. Of these, the percentage of rural residents is $31.1 \%$. In 10 years, the percentage of rural population has declined by about $16 \%$.

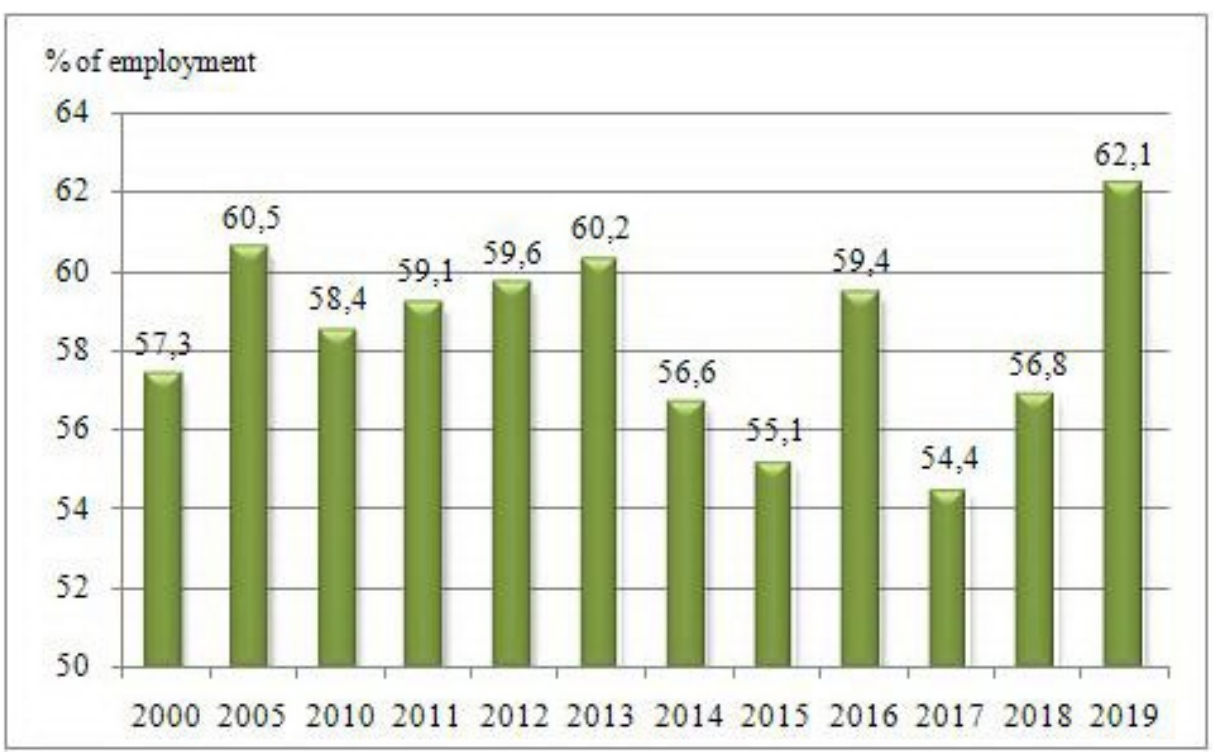

Fig. 6. Dynamics of the employment rate of the rural population of Ukraine (aged 15-70 years) [\%] Source: own study based on (State Statistic Service of Ukraine 2019)

Fig. 6. Dynamika wskaźnika zatrudnienia ludności wiejskiej Ukrainy (w wieku 15-70 lat) [\%]

Considering the constant growth of public debt, Ukraine needs to increase the production of final products inside the country, create additional value product and refuse to export raw materials.

According to the State Statistics Service of Ukraine in 2018, the agricultural sector generated about $13 \%$ of Ukrainian GDP. The share of agricultural products in total exports of Ukraine during this period amounted to $39.8 \%$, or USD 18.8 billion. Ukraine has 40 million hectares of agricultural land suitable for growing agricultural products. This makes it possible to meet the domestic demand for food products, exports and demand for biofuels.

Biofuel produced in Ukraine can be used both in Ukraine to reduce dependence on imports of fuel energy carriers, and be exported to European countries, where the production and con- 
sumption of bioethanol is constantly growing. Establishing the production and consumption of biofuels in Ukraine will help reduce energy dependence on fuel suppliers.

According to the calculations of Geletukha et al. 2020, Ukraine has a great potential of biomass for energy production - about 23 million tons of oil equivalent, according to 2018.

The energy potential of biomass of agricultural origin (approximately 11 million tons of oil equivalent per year) in Ukraine is more than 5 times higher than the potential of wood biomass, such as firewood, quarrying and wood processing waste (about 2 million tons of oil equivalent per year).

World experience shows that the production of biofuels provides benefits for the economy of each country, in particular, it provides an opportunity to create new jobs not only in rural areas but also in industrial centers, improves the environmental situation in the country, regions and more.

The study of the social effects of the consequences of the development of the biofuel industry can be presented through world experience. So, in 2018, the renewable energy industry created 10.98 million jobs in alternative energy and agriculture. The number of jobs created through the development of alternative energy in dynamics is shown in Figure 7.

One of the directions for the development of biofuel production in Ukraine is the implementation of measures in accordance with the Energy Strategy of Ukraine until 2035 "Safety, Energy Efficiency, Competitiveness".

Reforming the activities of energy companies in accordance with Ukraine's obligations under the Agreement on the Establishment of the Energy Community, increasing gas production, reducing the energy intensity of GDP and further developing renewable energy sources are the key tasks of the NPG implementation at this stage. The forecast indicators contained in the document demonstrate the trajectory of the development of energy and related industries. The predicted structure of energy supplies in Ukraine in accordance with the Energy Strategy of Ukraine is shown in Figure 8.

The strategy was developed taking the trends of geopolitical, macroeconomic, social and scientific and technological development of the country into account, which have certain risks of determining these factors. Therefore, it is necessary to ensure constant monitoring of the Energy Strategy and periodic clarification of the volumes and terms of work provided for by the strategy, taking the dynamics of prices for fuel and energy resources in the world and in the country, state development programs, achievements of scientific and technological progress, and improving environmental legislation into account.

Ensuring energy efficiency of the economy and the use of renewable energy resources play a vital role for Ukraine on the way to sustainable energy infrastructures.

It is forecasted that the share of fossil fuels in the energy mix will decline, and the necessary changes in its use will take place in favor of highly efficient technologies and fuels with less carbon per unit of energy. Alternative energy offers better opportunities for providing the population with jobs.

When determining the efficiency of biofuel production, it is important to determine both the financial profit and the intangible effect (Fig. 9). In particular, four main effects from the introduction of production and consumption of biofuels are determined: economic, environmental, 


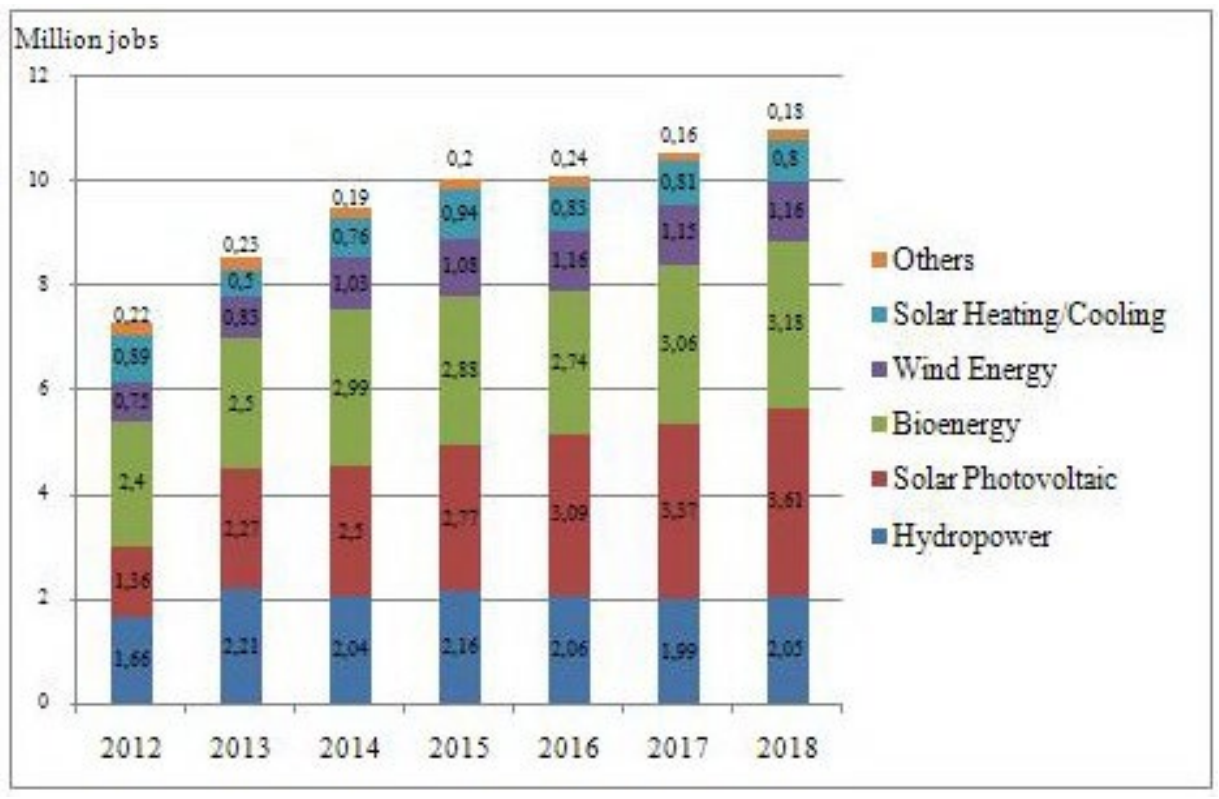

Fig. 7. Jobs created in the field of alternative energy

Source: own study based on (Renewable Energy and Jobs: Annual Review 2019)

Rys. 7. Miejsca pracy powstałe w wyniku rozwoju produkcji energii alternatywnej

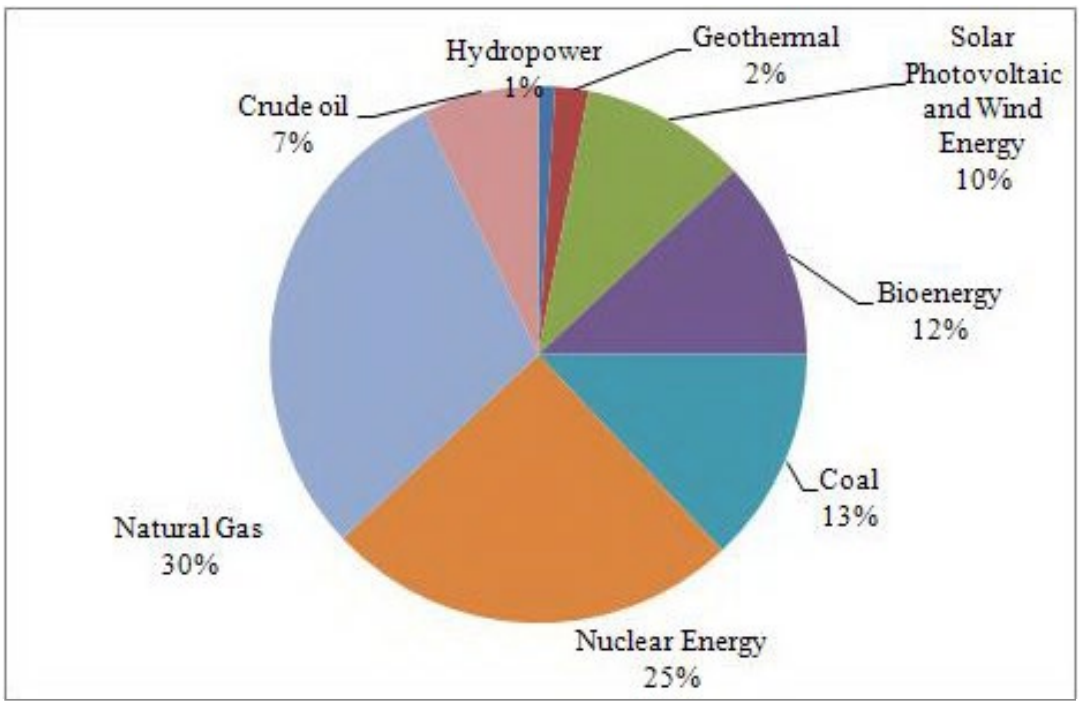

Fig. 8. Forecast structure of energy supplies in Ukraine in 2035

Source: own study based on (Energy Strategy of Ukraine for the period up to 2035 "Safety, Energy Efficiency, Competitiveness" 2017)

Rys. 8. Prognozowana struktura dostaw energii na Ukrainie w 2035 roku 
energy, and social. It is worth noting that all the effects from the introduction of the production and consumption of biofuels are closely related to each other, and are often the causes and consequences of each other.

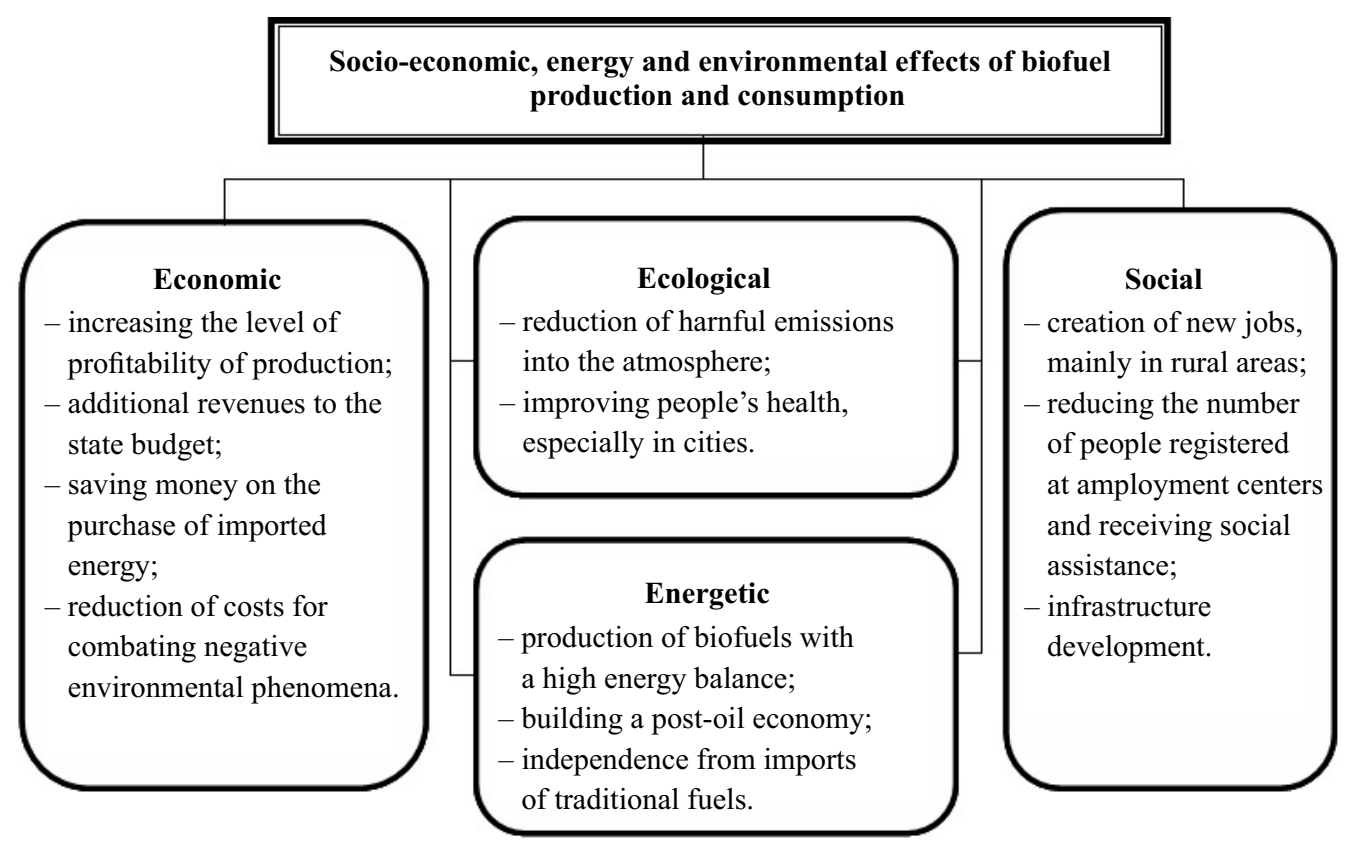

Fig. 9. The main effects that result from the production and consumption of biofuels (formed by the authors)

Rys. 9. Główne efekty wynikające z produkcji i zużycia biopaliw

The energy effect is to reduce dependence on imports of petroleum fuel by replacing it with domestic biofuels. Reducing the volume of fuel imports will strengthen the energy security of the state and avoid additional costs of the national currency for the purchase of imported energy resources.

The social effect of the production and consumption of biofuels is the creation of additional jobs, mainly in rural areas, and, as a consequence, a decrease in the number of disabled people and unemployment payments. Also, the additional equipment of additional lines for the production of biofuel and the construction of new plants have a positive effect on the development of the infrastructure of the surrounding areas.

The environmental effect is to reduce emissions of carbon dioxide and other harmful substances into the atmosphere, which arise as a result of the production, transportation, processing and use of oil and petroleum fuels. The use of biofuels in agriculture and in cities will have a positive impact on the environment and public health, reduce the cost of combating negative environmental phenomena and save the population on medicines. 
From an economic point of view, the price of biofuels is now largely dependent on the raw materials from which it is made and the technological process. However, when calculating the cost of biofuel production, the indirect effect of its use, namely energy, environmental and social effects, is not taken into account.

Different types of biofuels, depending on the raw materials used and production technologies, are characterized by certain positive and negative qualities. So, the negative properties of biofuels include: the high cost of biofuel plants, the rise in prices for agricultural products due to the use of food crops for biofuel production. However, these disadvantages are leveled out in comparison with the positive effects of biofuels.

Thus, the growth in the production of biofuels indicates that the advanced countries of the world will continue to support the development of its production and consumption. Ukraine, as an energy-dependent state with a powerful agricultural potential, should establish the efficient production and consumption of biofuels as soon as possible.

For Ukraine, biofuel production will have an extremely positive effect and will create a number of socio-economic and environmental benefits (Fig. 10).

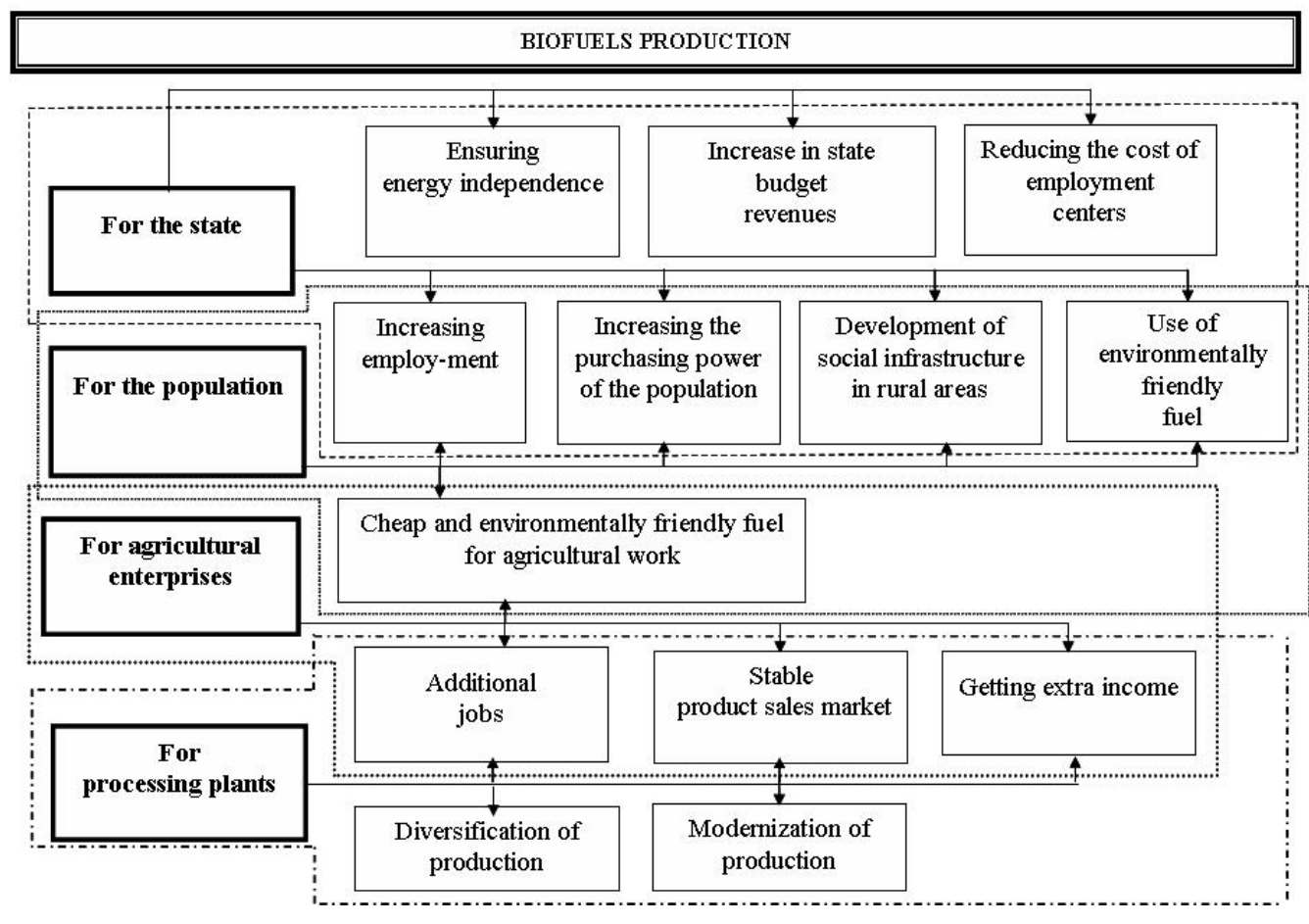

Fig. 10. Socio-economic benefits of biofuel production and consumption in Ukraine at different levels (formed by the authors)

Rys. 10. Korzyści społeczno-ekonomiczne z produkcji i zużycia biopaliw na Ukrainie na różnych poziomach 
The introduction of modern innovative technologies in the field of energy supply will reduce the dependence of the Ukrainian economy on oil and gas exporting countries, which, accordingly, will increase its energy, economic and national security and will contribute to our state's entry to a completely new level of relations with foreign countries - oil exporters and petroleum products and position itself as a state with a European level of economic and environmental security.

Choosing between exporting feedstock and processing it into a final product, we must proceed from the national interests of Ukraine. To overcome energy dependence, Ukraine must learn from the experience of the world's leading countries and establish the production of biofuels from agricultural raw materials.

\section{Conclusions}

The problem of using renewable energy sources is strategic for the development of the economy of most countries in general and their agro-industrial complex in particular, due to such objective factors: ensuring the state's energy security and reducing its dependence on energy imports; development and stability of the functioning of the country's agro-industrial complex; creating new jobs and increasing budget revenues; improvement of the ecological situation.

The main factors that induce the world community to produce biofuels are cost and environmental, since an important and valuable feature of biofuels is its regenerative nature, which creates opportunities for the agricultural sector to act as their producer and consumer.

Thus, biofuels production has two main missions: to reduce dependence on traditional fuels and their exporters, and to reduce greenhouse gas emissions into the environment. If we consider biofuels from a political and social perspective, we can add another positive property of this product - it can increase the independence of individual economic entities. Employment is an important social effect: every percentage of biofuels in total fuel consumption will create additional jobs in rural areas.

Ukraine cannot stand aside in the creation of bioenergy technologies for the production of biofuels, because this will mean its insecurity and low competitiveness of the economy on the international level. Given the unsightly energy and environmental situation, Ukraine should immediately begin the widespread introduction of bioenergy technologies using all types of biofuels - solid, liquid, gaseous. The development of production and consumption of biofuels should take place to ensure the energy, environmental, economic and food security of the state.

The production and use of biofuels in Ukraine will have a number of positive effects, including economic, environmental, energy and social. Biofuels production in Ukraine will contribute not only to reducing energy dependence, but also to improve the socio-economic and environmental situation. 
The availability of favorable climatic conditions, fertile soils and production facilities in Ukraine make it possible to grow and process a much larger amount of agricultural products than today. The establishment of biofuels production in Ukraine will contribute to the creation of new jobs and the social and infrastructural development of rural areas.

\section{References}

Berezyuk et al. 2019 - Berezyuk, S., Tokarchuk, D. and Pryshliak, N. 2019. Resource potential of waste usage as a component of environmental and energy safety of the state. Journal of Environmental Management and Tourism X, 5(37), pp. 1157-1167, DOI: 10.14505/jemt.v10.5(37).23.

DatTa et al. 2019 - Datta, A., Hossain, A. and Roy, S. 2019. An Overview on Biofuels and Their Advantages and Disadvantages. Asian Journal of Chemistry 31(8), pp. 1851-1858, DOI: 10.14233/ajchem.2019.22098

Energy Strategy of Ukraine for the period up to 2035 "Security, Energy Efficiency, Competitiveness". 2017. Resolution of the Cabinet of Ministers of Ukraine. [Online] https://zakon.rada.gov.ua/laws/show/605_2017_\%D1\%80 [Accessed: 2020-09-15].

Geletukha et al. 2020 - Geletukha, G.G., Oliynyk, E.M., Antonenko, V.O., Zubenko, V.I. and RadCHENKo, S.V. 2020. Agricultural residues for energy. What you should know about organizational and technical solutions. Position paper of UABIO. [Online] https:/uabio.org/wp-content/uploads/2020/09/ Analityka_UABIO_-energetychne-vykorystannia_agrovidhodiv_en.pdf [Accessed: 2020-09-18].

Guo, M. 2020. The Global Scenario of Biofuel Production and Development. [In:] Madhumi, M., Abhijit, N. (Eds.). Practices and Perspectives in Sustainable Bioenergy: A Systems Thinking Approach. Springer Nature, pp. 29-56.

IEA 2019. International Energy Agency: official website. [Online] https://www.iea.org/reports/global-energy-review-2019 [Accessed: 2020-09-10].

IRENA 2016. Innovation outlook: Advanced liquid biofuels, International Renewable Energy Agency, Abu Dhabi.

IRENA 2019. Advanced biofuels. What holds them back? International Renewable Energy Agency, Abu Dhabi.

KALETNIK, G. 2018. Production and use of biofuels: Second edition, supplemented: textbook. LLC "Nilan-Ltd", Vinnytsia.

Kaletnik et al. 2019 - Kaletnik, H., Pryshliak, V. and Pryshliak, N. 2019. Public Policy and Biofuels: Energy, Environment and Food Trilemma. Journal of Environmental Management and Tourism X, 3(35), pp. 479-487, DOI: 10.14505/jemt.v10.3(35).01.

Kovalko, M.P. and Kovalko, O.M. 2009. Developed energy as the basis of Ukraine's national security. Analysis of trends and opportunities. Kyiv: LLC "Drukarnia "Biznespolihraf", 104 p.

Lindsey, R. 2020. Climate Change: Atmospheric Carbon Dioxide. [Online] https://www.climate.gov/ news-features/understanding-climate/climate-change-atmospheric-carbon-dioxide [Accessed: 2020-09-15].

Msangi et al. 2006 - Msangi, S., Sulser, T., Rosegrant, M., Valmonte Santos, R. and Ringler, C. 2006. Global Scenarios for Biofuels: Impacts and Implications. Biofuels and Global Food Balance. [Online] http://www.fao.org/uploads/media/07_Global_Scenarios_for_Biofuels_Impacts_and_Implications_01.pdf [Accessed: 2020-09-20].

Он, Y. et al. 2018. Recent developments and key barriers to advanced biofuels: A short review. Bioresource Technology 257, pp. 320-333. 
OPEC Annual Statistical Bulletin. [Online] https://asb.opec.org/ [Accessed: 2020-09-10].

Organisation for Economic Co-operation and Development. [Online] https://data.oecd.org/pop/population. htm [Accessed: 2020-09-10].

PryshliaK, N. 2019. Biogas production in individual biogas digesters: experience of India and prospects for Ukraine. Agricultural and Resource Economics: International Scientific E-Journal 5(1). [Online] http://are-journal.com/are/article/view/226 [Accessed: 2020-09-10].

Pryshliak, N. and ToKarchuK, D. 2020. Socio-economic and environmental benefits of biofuel production development from agricultural waste in Ukraine. Environmental and Socio-Economic Studies 8(1), pp. $18-27$.

Pryshliak et al. 2020 - Pryshliak, N., Lutsiak, V., Tokarchuk, D. and Semchuk, I. 2020. The Empirical Research of the Potential, Awareness, and Current State of Agricultural Waste Use to Ensure Energy Autonomy of Agricultural Enterprises of Ukraine. Journal of Environmental Management and Tourism (Volume XI, Winter), 7(47), pp. 1634-1648, DOI: 10.14505/jemt.v11.7(47).04.

Ramos et al. 2016 - Ramos, J.-L., Valdivia, M. , García-Lorente, F. and Segura, A. 2016. Benefits and perspectives on the use of biofuels. Microbial Biotechnology 9(4), pp. 436-440.

Renewable Energy and Jobs: Annual Review 2019. [Online] https://www.irena.org/publications/2019/Jun/ Renewable-Energy-and-Jobs-Annual-Review-2019 [Accessed: 2020-09-05].

SHaH, A. 2012. Pros \& Cons of Biofuels. [Online] https://www.greenworldinvestor.com/2012/05/05/proscons-of-biofuels/ [Accessed: 2020-09-20].

State Statistics Committee of Ukraine. [Online] http://www.ukrstat.gov.ua [Accessed: 2020-09-10].

TisEO, I. 2020. Biofuels - production worldwide 2000-2019. [Online] https://www.statista.com/statistics/274163/global-biofuel-production-in-oil-equivalent [Accessed: 2020-09-20].

TOKARCHUK, D.M. 2019. The main trends in the formation and management of waste from agricultural enterprises. Economy. Finances. Management: current issues of science and practice 4 (44), pp. 170-180. DOI: $10.37128 / 2411-4413-2019-4-18$.

ToKarchuK et al. 2020 - ToKarchuK, D.M., Pryshliak, N.V., ToKarchuK, O.A. and MaZur, K.V. 2020. Technical and economic aspects of biogas production at a small agricultural enterprise with modeling of the optimal distribution of energy resources for profits maximization. INMATEH - Agricultural Engineering 61(2), pp. 339-349.

Uslu et al. 2018 - Uslu, A., Detz, R.J. and Mozaffarian, H. 2018. Barriers to advanced liquid biofuels \& renewable liquid fuels of non-biological origin. D1.1 Key barriers to advanced fuels - Results of the stakeholder consultation. [Online] https://ec.europa.eu/research/participants/documents/downloadPublic?documentIds=080166e 5bc3e33d0\&appId=PPGMS [Accessed: 2020-09-20].

Voloshin et al. 2019 - Voloshin, R.A., Rodionova, M.V., Zharmukhamedov, S.K., Veziroglu, T.N. and Allakhverdiev, S.I. 2019. Review: Biofuel Production from Plant and Algal Biomass. Alternative Energy and Ecology (ISJAEE) 7-9, pp. 12-31.

Winchester, N. and ReILly, J.M. 2015. The feasibility, costs, and environmental implications of largescale biomass energy. Energy Economics 51, pp. 188-203.

Zulauf et al. 2018 - Zulauf, C., Prutska, O., Kirieieva, E. and Pryshliak, N. 2018. Assessment of the potential for a biofuels industry in Ukraine. Problems and Perspectives in Management 16(4), pp. 83-90, DOI: 10.21511/ppm.16(4).2018.08. 


\section{Społeczno-ekonomiczne i środowiskowe znaczenie rozwoju biopaliw: przypadek Ukrainy na arenie międzynarodowej}

\section{Streszczenie}

Początek XXI wieku dał się poznać jako okres przejściowy w kształtowaniu się światowego systemu energetycznego. Obecnie aktualnymi problemami gospodarki są wzrost bieżących kosztów produkcji i konkretnych inwestycji w energetykę, kształtowanie sprzyjającego klimatu gospodarczego dla dalszego rozwoju kompleksu paliwowo-energetycznego, rozwój przez społeczność światową zaawansowanych regulacji, metod i skoordynowanych globalnych strategii rozwoju energetyki. Jednocześnie poprawa poziomu życia ludności i jej kondycji społeczno-ekonomicznej w dużej mierze zależeć będzie od racjonalnego wykorzystania nośników energii i potencjału zasobów naturalnych, co na obecnym etapie zarządzania nabiera szczególnego znaczenia.

Społeczno-ekonomiczna potrzeba zapewnienia większości krajów własnych źródeł energii rodzi problem ze znalezieniem paliw alternatywnych. Równocześnie coraz bardziej zauważalne są szkody dla środowiska spowodowane emisjami z samochodów napędzanych benzyną i olejem napędowym.

Jeśli chodzi o uzasadnienie ekonomicznej i społecznej konieczności kształtowania i rozwoju rynku biopaliw, należy wziąć pod uwagę kilka czynników, poczynając od względów bezpieczeństwa energetycznego, dywersyfikacji produkcji krajowej, wspierania innowacji, a kończąc na efektywności ekonomicznej i społecznej. Rozwój rynku biopaliw, poparty wysoką motywacją, pozwala na społeczne przesunięcie wzrostu zatrudnienia na obszary wiejskie i poprawę bezpieczeństwa środowiska dzięki odnawialnym źródłom energii.

SŁowA KLUCZOWE: efektywność energetyczna, ekologia, biopaliwa, rozwój obszarów wiejskich, efekt społeczny 
